\title{
Methodology for minimum nitrogen compounds removal efficiencies estimation and wastewater treatment systems pre-selection: a watershed approach
}

\author{
Metodologia para estimativa de eficiências mínimas de remoção de compostos \\ nitrogenados e pré-seleção de sistemas de tratamento de esgotos: uma abordagem para o \\ âmbito de bacias hidrográficas
}

\author{
Glaucia de Laia Nascimento Sá ${ }^{1}$ (D), José Antonio Tosta dos Reis ${ }^{1}$ (D), Antonio Sérgio Ferreira Mendonça ${ }^{1}$ (D) and \\ Fernando das Graças Braga da Silva² (D) \\ ${ }^{1}$ Universidade Federal do Espírito Santo, Vitória, ES, Brasil \\ ${ }^{2}$ Universidade Federal de Itajubá, Itajubá, MG, Brasil \\ E-mails: glaucialai@gmail.com (GLNS),jatreis@gmail.com (JATR), anserfm@terra.com.br (ASFM), ffbraga.silva@gmail.com (FGBS)
}

Received: October 26, 2018 - Revised: May 26, 2019 - Accepted: August 06, 2019

\begin{abstract}
Nitrogen is a very important parameter for water pollution control since nitrification implies in aquatic environment oxygen consumption and some nitrogen forms are toxic. In the present study, an optimization model was developed and applied aiming at simultaneous organic matter and nitrogen compounds minimum removal efficiencies determination. A water quality model and the Genetic Algorithm Metaheuristic were associated in order to solve the optimization problem. The estimated minimum efficiencies conditioned the sewage treatment systems pre-selection. The study area was the Pardo River watershed (Espírito Santo State, Brazil). The results indicate that the treatment systems need to be more efficient in ammonia removal when the treated effluents disposed in watercourses that present high $\mathrm{pH}$ values because ammonia toxicity increases with $\mathrm{pH}$. Considering the boundary conditions assumed in this study, the pre-selection process indicated activated sludge systems, submerged aerated biofilter with nitrification, or with biological nitrogen removal, for Ibatiba city. Simpler systems such as primary treatment with septic tanks, stabilization ponds, UASB reactors and biological filters were pre-selected for Santíssima Trindade and Nossa Senhora das Graças towns.
\end{abstract}

Keywords: Nitrogen; Water quality model; Optimization; Genetic algorithm; Sewage treatment.

\section{RESUMO}

O nitrogênio constitui importante parâmetro para o controle da poluição hídrica, uma vez que a nitrificação produz consumo de oxigênio do ambiente aquático, além da toxicidade associada à algumas formas de nitrogênio. Este estudo estabeleceu e empregou modelo de otimização visando a determinação simultânea de eficiências mínimas de remoção de demanda bioquímica de oxigênio e compostos de nitrogênio. Para resolução do modelo de otimização foram associados modelo de qualidade da água e a Metaheurística Algoritmo Genético. As eficiências mínimas estimadas condicionaram a pré-seleção de sistemas de tratamento de esgotos. A área de estudo foi a bacia hidrográfica do rio Pardo (Espírito Santo, Brasil). Os resultados indicaram que, função do aumento da toxicidade da amônia com a elevação de $\mathrm{pH}$, os sistemas de tratamento precisam ser mais eficientes na remoção de amônia, quando da disposição dos efluentes tratados em cursos d'água com elevados valores de $\mathrm{pH}$. O processo de pré-seleção, consideradas as condições de contorno assumidas neste estudo, indicou para Ibatiba sistemas de lodos ativados, biofiltro aerado submerso com nitrificação ou com remoção biológica de nitrogênio. Para os povoados Santíssima Trindade e Nossa Senhora das Graças foram pré-selecionados sistemas mais simples como tratamento primário com tanques sépticos, lagoas de estabilização, reatores UASB e filtros biológicos.

Palavras-chave: Nitrogênio; Modelo de qualidade de água; Otimização; Algoritmo genético; Tratamento de esgotos. 
Methodology for minimum nitrogen compounds removal efficiencies estimation and wastewater treatment systems pre-selection: a watershed approach

\section{INTRODUCTION}

Effluents treatment before discharge, either individual or collective, is the main strategy for water bodies' pollution control. The required treatment level depends on effluent characteristics, receiving watercourse class and self-purification capacity. (JORDÃO; PESSOA, 2014).

In water resources management, treatment cost can be as important as the water quality goals to be achieved. Moreover, high investments in pollution control may not be feasible in developing countries (CHO; SUNG; HA, 2004). An ideal treatment plant should be associated with minimum contaminant discharges, minimum treatment costs, and maximum sociocultural benefits (ZENG et al., 2007). Hence, watercourses self-purification capacity studies become relevant allies of the decision-making processes associated to the effluent treatment systems selection. Watercourses self- depuration consideration can provide significant treatment costs reduction.

Adequate self-purification capacities estimation allows the evaluation of the effluents constituents maximum loads to the receiving water bodies, indicating minimum removal levels for the different constituents present in the raw sewage and, consequently, establishing minimum sewage treatment systems removal efficiencies (VALORY; REIS; MENDONÇA, 2013).

Mathematical water quality modeling is an important tool for water resources management. Particularly, it allows watercourse self-purification capacity simulation by representing water quality conditions spatial and temporal variability in the region of interest, considering point and diffuse pollution sources (LARENTIS, 2004).

Mathematical water quality models do not necessarily provide an optimal solution for the treated effluents allocation problem, although allowing the evaluation of large number of viable solutions for the minimum discharge points effluents treatment efficiencies determination problem. Thus, the combined application of optimization techniques and water quality mathematical modelling represents an interesting methodological alternative which can contribute to the decision-making process and, consequently, to water resources planning and management.

Although the current technical literature presents works, analysis of the environmental standards associated with Biochemical Oxygen Demand (BOD) and Dissolved Oxygen (DO) (SAADATPOUR; AFSHAR, 2007; ALBERTIN, 2008; ANDRADE; MAURI; MENDONÇA, 2013; FEIZI ASHTIANI; NIKSOKHAN; ARDESTANI, 2015; VALORY; REIS; MENDONÇA, 2016; SANTORO; REIS; MENDONÇA, 2016; FANTIN; REIS; MENDONÇA, 2017; BRINGER; REIS; MENDONÇA, 2018), effluent loads allocation studies involving other quality parameters, such as nutrients and faecal contamination indicators, even being necessary, are not usual.

The present work aims to develop an optimization model applicable to sewage treatment systems nitrogen and BOD minimum removal efficiencies determination, considering environmental water quality standards established by legislation, and overall sewage treatment effort within a river basin minimization. It also intends to demonstrate wastewater treatment systems pre-selection considering estimated minimum removal levels.

The Pardo River, a tributary of the Itapemirim River (the most important watercourse located in the southern region of the Espírito Santo State, Brazil) watershed, was considered to illustrate the proposed optimization model application and to demonstrate the developed combined use of water quality model and optimization technique methodology application.

\section{STUDY AREA}

Although applicable to any river basin, the methodology proposed in this study was applied to the Pardo River watershed (Figure 1), an important tributary of the Itapemirim River, a

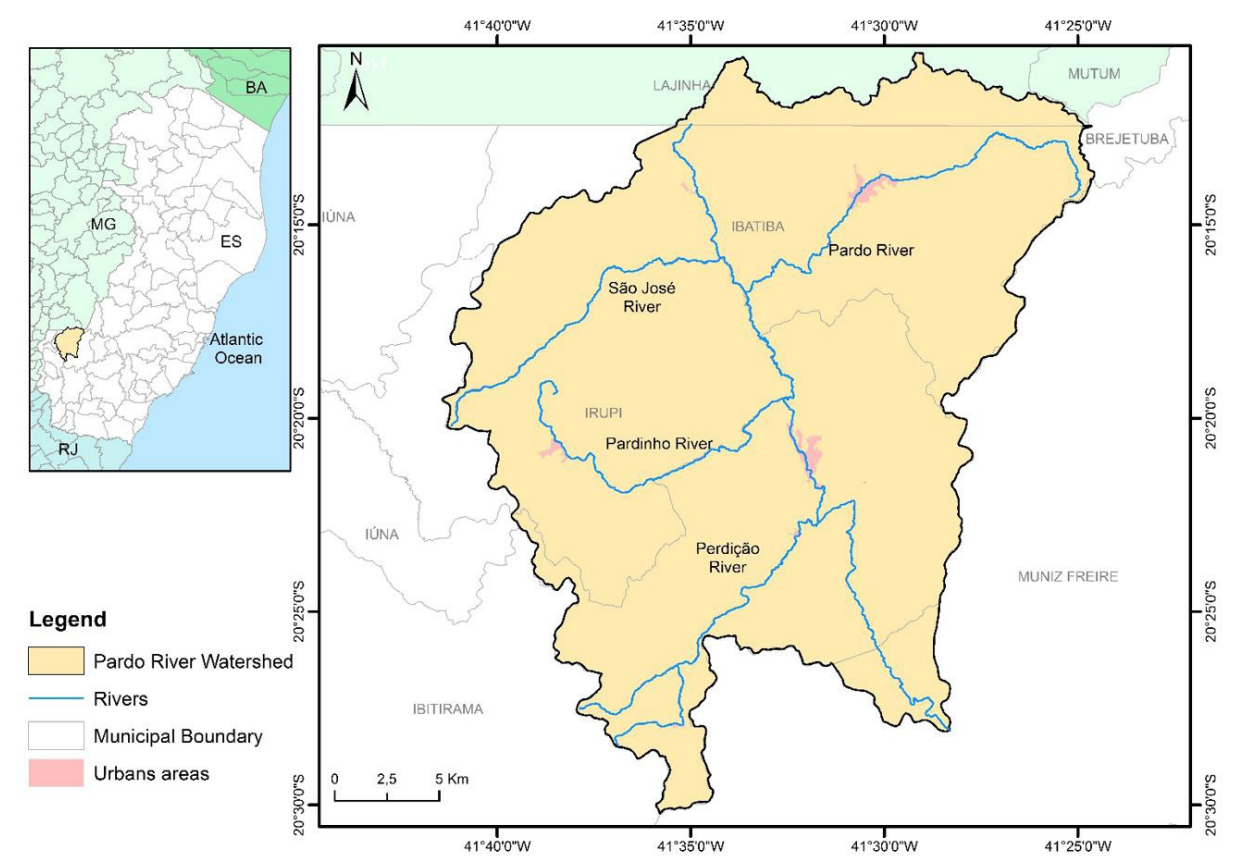

Figure 1. Pardo River watershed location. 


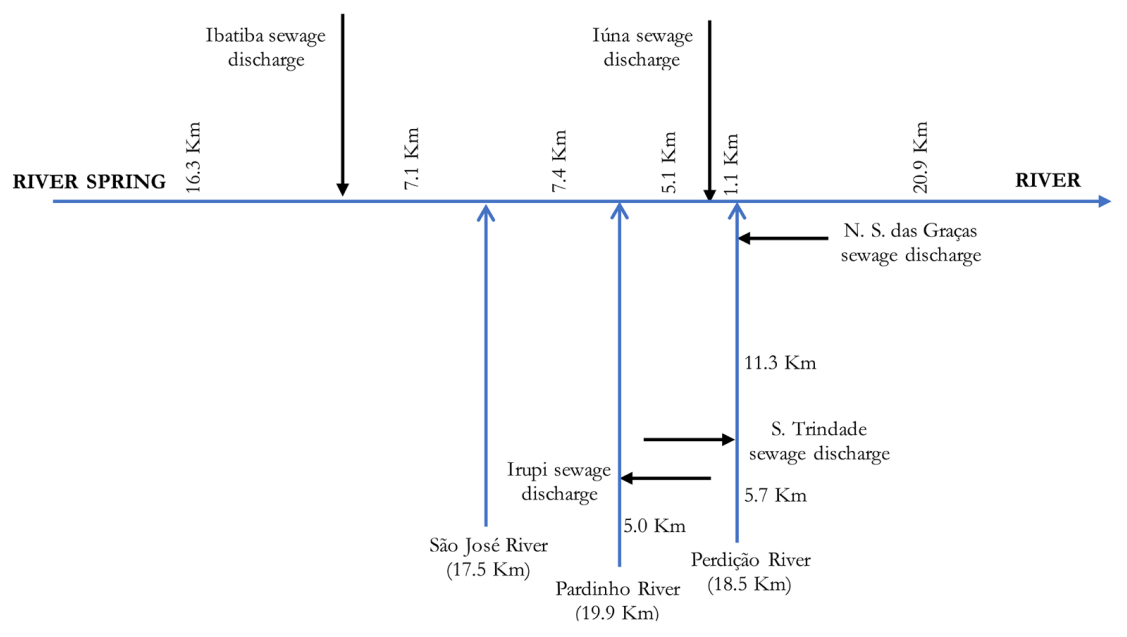

Figure 2. Pardo River watershed single-line diagram.

watercourse located in the southern region of the Espírito Santo State. Figure 2 displays a single-line diagram presenting the main Pardo River watershed watercourses. Pardo River watershed drainage area corresponds to approximately $611 \mathrm{~km}^{2}$. The watershed includes parts of four counties located in Espírito Santo State (Ibatiba, Irupi, Iúna, and Muniz Freire) and one county located in Minas Gerais State (Lajinha). The Pardo River starts in Ibatiba county and is approximately $57.9 \mathrm{~km}$ long. The main Pardo River tributaries are São José River, Pardinho River and Perdição River.

Pardo River receives directly the raw domestic sewage generated in Ibatiba and Iúna cities. The Pardinho River receives the sewage generated in Irupi town. Perdição River receives the sewage generated in Santíssima Trindade and Nossa Senhora das Graças towns. There are no sewage treatment plants operating at any of the above-mentioned raw sewage generation places.

\section{MATERIAL AND METHODS}

The methodology developed in this study involves, within a river watershed, the association of a water quality simulation model with an optimization technique to obtain minimum wastewater treatment systems BOD and nitrogen removal efficiencies, besides pre-selection of systems which present removal levels compatible with those minimum estimated. In the following items different aspects associated with minimum treatment efficiencies determination and sewage treatment systems pre-selection processes will be presented.

\section{BOD and nitrogen minimum removal efficiencies}

\section{Water quality mathematical modeling}

Water quality simulation was performed by a mathematical model developed in the MatLab software environment. The model, based on the QUAL-UFMG model, describes the spatial variation of DO, BOD, total nitrogen and its fractions (organic nitrogen, ammoniacal nitrogen, nitrite and nitrate) along watercourses.
The phenomena considered in the water quality parameters modeling were the deoxygenation due to oxidation of organic matter carbonaceous fraction; nitrification due to ammonia oxidation; sediment oxygen demand and atmospheric reaeration. Modeling did not consider oxygen production by photosynthesis and oxygen consumption by respiration.

The physiographic characteristics, raw effluents kinetic constants, hydrodynamic information, organic loads and raw effluents flows (Table 1) reproduced those obtained by Calmon et al. (2016). These authors developed a methodological procedure to support surface watercourses classification processes that was applied to the same watershed analyzed in the present study.

The river BOD decomposition coefficient, $K_{d}$, was determined according to the water body hydraulic characteristics (depth and flow), by means of an equation proposed by Hydroscience Inc. (1971). The reaeration coefficient, $K_{2}$. , was also obtained by correlation with hydraulic variables, from the formulation originally determined by O'Connor and Dobbins (1958 apud BOWIE et al., 1985). The sedimentation coefficient, $K_{s}$, adopted in this work was $0.05 \mathrm{~d}^{-1}$. The choice of these values was based on the range of typical values for shallow rivers receiving low concentration sewage, as presented by Von Sperling (2014b). It is important to note that the assumed value for $K_{s}$ is in favor of safety since it represents the coefficient typical values range lower limit, corresponding to limited reduction of the BOD quantity in the liquid mass due to sedimentation.

The coefficient that expresses the sediment oxygen demand, $S_{d}{ }^{\prime}$, defined from the values proposed by Aguirre Júnior (2000), was assumed to be $0.50 \mathrm{~g} \mathrm{O}_{2} \cdot \mathrm{m}^{-2} \cdot \mathrm{d}^{-1}$ in this study. The adopted nitrogen compounds reaction coefficients were the central values of the ranges presented by Von Sperling (2014b).

The kinetic coefficients values were corrected, function of the temperature adopted in the present work, by considering the temperature coefficient typical values $(\theta)$ indicated in the literature: 1.024 for $K_{2}, K_{s}, K_{s o}$ (BOWIE et al., 1985); 1.047 for $K_{d}, K_{o a}, K_{n n}$; 1.060 for $S_{d}^{\prime}$ (USEPA, 1987); and 1.080 for $K_{a n}$ (THOMANN; MUELLER, 1987). 
Methodology for minimum nitrogen compounds removal efficiencies estimation and wastewater treatment systems pre-selection: a watershed approach

Table 1. Physiographic characteristics, raw effluents kinetic constants, hydrodynamic information, loads and Pardo River watershed effluent flows.

\begin{tabular}{|c|c|}
\hline Parameter & Value \\
\hline Average altitude & $846.36 \mathrm{~m}$ \\
\hline Average temperature & $20.6^{\circ} \mathrm{C}$ \\
\hline Oxygen saturation concentration & $8.11 \mathrm{mg} \cdot \mathrm{L}^{-1}$ \\
\hline Watercourses incremental flow & 3.53 L.s ${ }^{-1}$ \\
\hline Watercourses DO $\left(D O_{r}\right)$ & $7.5 \mathrm{mg} . \mathrm{L}^{-1}$ \\
\hline Watercourses BOD $\left(B O D_{r}\right)$ & $2 \mathrm{mg} \cdot \mathrm{L}^{-1}$ \\
\hline Watercourses Organic Nitrogen $\left(N_{\text {orgr }}\right)$ & 1 mg.L.-1 \\
\hline Ammonia in the watercourses $\left(N_{\text {amonr }}\right)$ & $1 \mathrm{mg} \cdot \mathrm{L}^{-1}$ \\
\hline Nitrite in the watercourses $\left(N_{\text {nitrir }}\right)$ & $0 \mathrm{mg} \cdot \mathrm{L}^{-1}$ \\
\hline Nitrate in the watercourse $\left(N_{\text {nitrar }}\right)$ & 0 mg. $\mathrm{L}^{-1}$ \\
\hline Sewage BOD & $400 \mathrm{mg} \cdot \mathrm{L}^{-1}$ \\
\hline Ibatiba sewage discharge flow rate & $24.3{\mathrm{~L} . \mathrm{s}^{-1}}^{-1}$ \\
\hline Irupi sewage discharge flow rate & 5.20 L.s $^{-1}$ \\
\hline Iúna sewage discharge flow rate & $19.90{\mathrm{~L} . \mathrm{s}^{-1}}^{2}$ \\
\hline S. Trindade sewage discharge flow rate & 0.30 L.s $^{-1}$ \\
\hline N. S. das Graças sewage discharge flow rate & $0.60{\mathrm{~L} . \mathrm{s}^{-1}}^{-1}$ \\
\hline Direct incremental BOD load & 9.35 g.day ${ }^{-1} \cdot \mathrm{m}^{-1}$ \\
\hline Sedimentation coefficient $(K)$ & $0.05 \mathrm{day}^{-1}$ \\
\hline Organic N Sedimentation coefficient (Kso) & $0.05 \mathrm{~d}^{-1}$ \\
\hline Organic $\mathrm{N}$ to ammonia conversion coefficient (Koa) & $0.225 \mathrm{~d}^{-1}$ \\
\hline Ammonia to nitrite conversion coefficient (Kan) & $0.20 \mathrm{~d}^{-1}$ \\
\hline Nitrite to nitrate conversion coefficient (Knn) & $0.50 \mathrm{~d}^{-1}$ \\
\hline Flow of ammonia released by the bottom sediment (Samon) & $0.25 \mathrm{~g} \cdot \mathrm{m}^{-2} \cdot \mathrm{d}^{-1}$ \\
\hline Coefficient of nitrification inhibition because of low DO (KnitrDO) & $0.60 \mathrm{~L} \cdot \mathrm{mg}^{-1}$ \\
\hline Ratio of oxygen consumed by each unit of ammonia oxidized to nitrite (RO2amon) & $3.2 \mathrm{mg}$ O2.mg Namon ${ }^{-1}$ \\
\hline Ratio of oxygen consumed by each unit of nitrite oxidized to nitrate (RO2nitri) & $1.1 \mathrm{mg}$ O2.mg Nitri ${ }^{-1}$ \\
\hline
\end{tabular}

Pardo river basin water quality simulations were carried out for the following scenarios regarding organic nitrogen and ammonia effluent concentrations:

- Scenario 1: The effluents organic nitrogen concentration was considered $30 \mathrm{mg} . \mathrm{L}^{-1}$ the maximum value of the range of typical values proposed by Von Sperling (2014b) for domestic effluents. The effluents ammonia concentration was considered $50 \mathrm{mg} \cdot \mathrm{L}^{-1}$, the maximum value proposed by Feigin et al. (1991 apud NYENJE et al., 2010). In this work, conservative values were adopted for domestic sewage organic nitrogen and ammonia concentrations for safety reasons, since the higher the raw sewage nitrogen compounds concentrations, the higher the minimum removal levels of these constituents in order to ensure compliance with environmental quality standards;

- Scenario 2: From the organic nitrogen and ammonia concentrations values adopted in Scenario 1, it was considered that all the organic nitrogen domestic sewage concentration was converted to ammonia through the ammonification process, adopting null concentration for organic nitrogen and $80 \mathrm{mg} \cdot \mathrm{L}^{-1}$ for ammonia concentration.

\section{Optimization model}

The optimization model formulation in this study was based on the one originally proposed by Valory, Reis and Mendonça (2013), which sought to minimize the sum of the sewage treatment BOD removal efficiencies values in the Pardo River watershed.
However, the model proposed in this study seeks to determine the minimum BOD and ammoniacal nitrogen removal efficiencies simultaneously.

This optimization model was applied to three discharge conditions. Firstly, the discharge condition 1 considered the use of the rivers self-purification capacities for effluents assimilation without the imposition of effluents quality standard. Secondly, the discharge condition 2 considered maximum BOD concentration in the effluent equal to $120 \mathrm{mg} \cdot \mathrm{L}^{-1}$. Lastly, the discharge condition 3 considered the BOD removal efficiency at least $60 \%$. Furthermore, it is important to note that the last two discharge conditions were established according to Brazilian National Environment Council (CONAMA) Resolution 430/2011 Article 21, which defines sewage discharge conditions with respect to BOD concentrations (BRASIL, 2011).

In this model, the objective function, represented by Equation 1, has two summands, one referring to the BOD removal efficiency, and another to nitrogen removal efficiency.

Minimize $[f(E)]=\sum_{i=1}^{n} E_{B O D_{i}}+\sum_{j=1}^{n} E_{\text {Namon }_{j}}$

$E_{B O D_{i}}$ and $E_{\text {Namon }_{j}}$ values are the pairs of BOD and ammoniacal nitrogen removal efficiencies for each Pardo River watershed sewage discharge. The proposed optimization model assumed the basic hypothesis that the removal of organic matter and nitrogenous compounds are equally important. It may be noted that it is allowed different perspectives accommodation through eventual incorporation of weights to the summands that make up the objective function. The constraints regarding limits for effluent constituent removal efficiencies and quality standards 
established by CONAMA Resolution 357/2005 considered in the optimization model were those presented by Inequalities 2 to 13 .

The study area watercourses did not undergo classification process. Hence, they were considered class 2 , as recommended by CONAMA Resolution 357/2005 (BRASIL, 2005).

$$
\begin{aligned}
& E_{B D O_{i}} \geq 0 \% \\
& E_{B D O_{i}} \leq 90 \% \\
& B D O_{r} \leq 5.0 \\
& D O_{r} \geq 5.0 \\
& E_{\text {Namon }_{i}} \geq 0 \% \\
& E_{\text {Namon }_{j}} \leq 90 \% \\
& N_{\text {nitrir }}<1.0 \\
& N_{\text {nitrar }}<10.0 \\
& N_{\text {amonr }}<3.7 \text { for } p H \leq 7.5 \\
& N_{\text {amonr }}<2.0 \text { for } 7.5 \leq p H \leq 8.0 \\
& N_{\text {amonr }}<1.0 \text { for } 8.0 \leq p H \leq 8.5 \\
& N_{\text {amonr }}<0.5 \text { para } p H>8.5
\end{aligned}
$$

\section{Optimization technique}

The proposed optimization model application was performed by the Genetic Algorithm (GA) optimization technique, with the aid of the Optimization toolbox, available in the MatLab software. This technique presents as main operators the type of selection, crossover, and mutation; and as the main parameters the initial population size, elitism, recombination probability and mutation probability.

Table 2 shows the operators and parameters adopted in this study, which reproduced the values tested and proposed by Valory, Reis and Mendonça (2016) when evaluating minimum sewage treatment efficiencies for fictitious sewage discharges located in the upper region of the Santa Maria da Vitória River (Espírito Santo State, Brazil).

\section{Wastewater treatment systems pre-selection}

Treatment systems were pre-selected for the five sewage final disposal points located in the Pardo River watershed based on the BOD and ammonia minimum removal efficiencies.
Table 2. GA application operators and parameters.

\begin{tabular}{lc}
\hline \multicolumn{1}{c}{$\begin{array}{c}\text { Operator/ } \\
\text { Parameter }\end{array}$} & Value/Type \\
\hline Codification & Real \\
Population Size & 300 individuals \\
Selection type & Tournament Selection (10 individuals group) \\
Crossover type & Arithmetic \\
Crossover rate & $50 \%$ \\
Mutation type & Adaptive \\
Stopping criteria & 100 generations or convergence \\
Elitism & 3 individuals \\
\hline
\end{tabular}

Source: Valory, Reis and Mendonça (2016).

The BOD and ammonia removal efficiencies reference values for each treatment system considered in the pre-selection, presented in Table 3, correspond to the central values of the removal efficiencies ranges presented by Von Sperling (2014a). However, it is important to note that the sewage treatment systems removal efficiencies vary according to the characteristics of the sewage to be treated, the climatic conditions (in particular with the ambient temperature, whose values present daily and seasonal variations), the wastewater treatment plant (WWTP) operation conditions, among other factors. Thus, the adoption of reference values for treatment efficiencies is a very important part of the treatment systems pre-selection process since it may eventually lead to the suggestion of a diversified set of sewage treatment systems.

Systems that require electric power for aeration were not considered for the Santíssima Trindade and Nossa Senhora das Graças towns (located in Iúna county), hence imposing a limitation on energy consumption. However, treatment systems associated with effluents final disposal in the soil were accepted since these communities present very small numbers of inhabitants (which leads to low final effluent outflows), thus not requiring significant areas for soil disposal. On the other hand, the treatment alternatives associated with final effluent disposal in the soil were not considered for Ibatiba, Iúna, and Irupi cities. These urban areas are more populated and their effluents volumes to be disposed would demand large areas, which could eventually make this treatment type option not feasible.

\section{RESULTS AND DISCUSSION}

The results of the application of the methodology proposed in this study to the Pardo River watershed are presented in three stages. The first stage discusses the self-purification capabilities of the watercourses that receive domestic sewage discharges without any kind of treatment. Then, the sewage BOD and nitrogen removal efficiencies are presented. They were estimated for each locality by association between the water quality model and the optimization technique. Lastly, the sewage treatment systems pre-selection results are presented and discussed for each of the locations currently discharging raw sewage into the watershed watercourses. 
Methodology for minimum nitrogen compounds removal efficiencies estimation and wastewater treatment systems pre-selection: a watershed approach

Table 3. Wastewater treatment systems considered in the pre-selection stage.

\begin{tabular}{|c|c|c|c|}
\hline & \multirow{2}{*}{ Treatment Alternatives } & \multicolumn{2}{|c|}{ Average Removal Efficiencies (\%) } \\
\hline & & BOD & Ammonia \\
\hline A01 & Primary treatment & 32.5 & 30 \\
\hline A02 & Conventional primary treatment & 32.5 & 30 \\
\hline A03 & Advanced primary treatment & 62.5 & 30 \\
\hline A04 & Facultative pond & 80 & 50 \\
\hline A05 & Anaerobic pond - facultative pond & 80 & 50 \\
\hline A06 & Aerated facultative pond & 80 & 30 \\
\hline A07 & Comp. mixed aerated pond + sedim. pond & 80 & 30 \\
\hline A08 & Anaerobic pond + facultative pond + maturation pond & 82.5 & 57.5 \\
\hline A09 & Anaerobic pond + facultative pond + high rate pond & 82.5 & 75 \\
\hline A10 & Anaerobic pond + facultative pond + algae removal & 87.5 & 50 \\
\hline A11 & Slow infiltration & 94.5 & 80 \\
\hline A12 & Fast infiltration & 91.5 & 65 \\
\hline A13 & Surface runoff & 85 & 50 \\
\hline A14 & Wetlands & 85 & 50 \\
\hline A15 & Septic tank + anaerobic filter & 82.5 & 45 \\
\hline A16 & Septic tank + infiltration & 94 & 65 \\
\hline A17 & UASB Reactor & 67.5 & 50 \\
\hline A18 & UASB + activated sludge & 88 & 67.5 \\
\hline A19 & UASB + submerged aerated biofilter & 88 & 67.5 \\
\hline A 20 & UASB + anaerobic filter & 81 & 50 \\
\hline A21 & UASB + high load perc. biol. filter & 86.5 & 50 \\
\hline A 22 & UASB + dissolved air flotation & 88 & 30 \\
\hline A23 & UASB + polishing ponds & 82 & 57.5 \\
\hline A24 & $\mathrm{UASB}+$ aerated facultative pond & 80 & 30 \\
\hline A25 & UASB + comp. mixed aerated pond + decantation pond & 80 & 30 \\
\hline A26 & UASB + surface runoff & 83.5 & 50 \\
\hline A27 & Conventional activated sludge & 89 & 80 \\
\hline A28 & Activated sludge - extended aeration & 93.5 & 80 \\
\hline A29 & Activated sludge - batch treatment & 93.5 & 80 \\
\hline A 30 & Conventional activated sludge with biological $\mathrm{N}$ removal & 89 & 80 \\
\hline A31 & Conventional activated sludge with biological N/P removal & 89 & 80 \\
\hline A32 & Conventional activated sludge + tertiary infiltration & 95.5 & 80 \\
\hline A33 & Low load percolator biological filter & 89 & 75 \\
\hline A34 & High load percolator biological filter & 85 & 50 \\
\hline A35 & Submerged aerated biofilter with nitrification & 91.5 & 80 \\
\hline A36 & Submerged aerated biofilter with biological $\mathrm{N}$ removal & 91.5 & 80 \\
\hline A 37 & Biodisc & 91.5 & 75 \\
\hline
\end{tabular}

Source: Von Sperling (2014a).

\section{Simulation of the raw sewage discharge}

The initial simulation generated concentration profiles for the water quality different parameters when considering the current Pardo River watershed condition (raw sewage discharge in five disposal points located in the watershed). DO, BOD, organic nitrogen, ammoniacal nitrogen, nitrite and nitrate concentration profiles were obtained for the three Pardo River watershed watercourses that receive sewage discharges (Pardo River, Pardinho River and Perdição River) taking into account the scenarios established by the different distribution of total nitrogen concentrations between organic nitrogen and ammonia.

Table 4 presents, for each watercourse that receives sewage discharge in the studied watershed, DO, BOD, ammoniacal nitrogen, nitrite and nitrate critical concentrations obtained by simulating the water quality conditions for scenario 1 (effluents organic and ammoniacal nitrogen concentrations 30.0 mg.L $\mathrm{L}^{-1}$ and $50.0 \mathrm{mg} . \mathrm{L}^{-1}$, respectively).

Based on CONAMA Resolution 357/2005 DO concentration limit for class 2 rivers and from the concentration profiles generated by the water quality model, it was observed that DO concentrations remained above the minimum, $5.0 \mathrm{mg} . \mathrm{L}^{-1}$, even for raw sewage discharge. On the other hand, for BOD, the Pardo and Pardinho Rivers presented concentrations above the maximum limit, $5.0 \mathrm{mg} . \mathrm{L}^{-1}$, hence in disagreement with the quality standard established for class 2 rivers. Regarding to the different nitrogen forms, even with raw sewage inflow, the concentrations are in accordance with the quality standard defined for class 2 rivers, if water $\mathrm{pH}$ values remain below 7.5.

Figure 3 shows the DO and BOD profiles along the Pardo River, and Figure 4 shows the nitrogen compounds (organic, ammoniacal, nitrite and nitrate) profiles for the same watercourse. 
Table 4. Critical concentrations for Scenario 1.

\begin{tabular}{|c|c|c|c|c|c|}
\hline Watercourse & $\begin{array}{c}\text { DO } \\
\left(\mathrm{mg} \cdot \mathrm{L}^{-1}\right)\end{array}$ & $\begin{array}{c}\text { BOD } \\
\left(\mathrm{mg} \cdot \mathrm{L}^{-1}\right)\end{array}$ & $\begin{array}{c}\text { Ammonia } \\
\left(\mathrm{mg} \cdot \mathrm{L}^{-1}\right)\end{array}$ & $\begin{array}{l}\text { Nitrite } \\
\left(\mathrm{mg} \cdot \mathrm{L}^{-1}\right)\end{array}$ & $\begin{array}{l}\text { Nitrate } \\
\left(\mathrm{mg} \cdot \mathrm{L}^{-1}\right)\end{array}$ \\
\hline Pardo River & 5.04 & 18.46 & 3.58 & 0.49 & 0.38 \\
\hline Pardinho River & 5.60 & 14.12 & 3.01 & 0.39 & 0.24 \\
\hline Perdição River & 6.59 & 4.43 & 1.69 & 0.30 & 0.18 \\
\hline Environmental Quality Standards & 5.00 & 5.00 & (1) & 1.00 & 10.00 \\
\hline
\end{tabular}

${ }^{(1)}$ The environmental standard for ammonia depends on the water body pH. For pH values less than 7.5, $3.7 \mathrm{mg} \cdot \mathrm{L}^{-1}$; pH in-between 7.5 and 8.0, 2.0 mg.L ${ }^{-1}$; $\mathrm{pH}$ in-between 8.0 and $8.5,1.0 \mathrm{mg} \cdot \mathrm{L}^{-1} ; \mathrm{pH}$ values higher than $8.5,0.5 \mathrm{mg} \cdot \mathrm{L}^{-1}$.

Pardo River BOD profile (Figure 3) shows two concentration peaks, related with domestic sewage inflows of Ibatiba $(\mathrm{km} \mathrm{16.3)}$ and Iúna (km 35.9), reaching $18.46 \mathrm{mg} . \mathrm{L}^{-1}$, and $6.89 \mathrm{mg} . \mathrm{L}^{-1}$, respectively. In addition, this profile shows BOD concentration decreases at the three points where the Pardo River receives São José, Pardinho and Perdição tributaries, at kilometers 23.4, 30.8, and 37.0, respectively. São José River affluence contributes to the increase in the Pardo River organic matter dilution because it does not receive sewage discharges. Conversely, Pardinho River receives domestic sewage discharge in Irupi and contributes to the increase of the Pardo river flow without, however, causing increase in the BOD concentration. Perdição River receives very low domestic sewage contributions from Santíssima Trindade and Nossa Senhora das Graças, and its water reaches the Pardo River with low organic matter concentrations (lower than those estimated for the Pardo river) due to its self-purification capacity.

Pardo River DO profile (Figure 3) indicates that the increase in BOD concentration by the Ibatiba domestic sewage discharge caused significant DO consumption DO minimum concentration was equal to $5.04 \mathrm{mg} \cdot \mathrm{L}^{-1}$. Additionally, there was an increase, although very low, in DO concentrations due to São José River, Pardinho River and Perdição River tributaries inflows.

Pardo River organic and ammoniacal nitrogen profiles (Figure 4) showed concentration peaks at the domestic sewage discharge points located in Ibatiba and Iúna cities, and in concentrations reductions at points where tributaries inflow. Organic nitrogen concentrations estimated by the quality model reached $1.89 \mathrm{mg} . \mathrm{L}^{-1}$ and $1.08 \mathrm{mg} . \mathrm{L}^{-1}$ at Ibatiba and Iúna domestic sewage discharge points, respectively. Ammonia concentrations estimated by the quality model reached $3.58 \mathrm{mg} . \mathrm{L}^{-1}$ and $2.45 \mathrm{mg} . \mathrm{L}^{-1}$ at the same discharge points.

It is important to note that CONAMA Resolution 357/2005 establishes quality standards for nitrogen compounds in freshwater bodies according to class and $\mathrm{pH}$ range (Table 1). The maximum ammonia concentration obtained by the water quality model (3.58 mg. $\mathrm{L}^{-1}$ ) was lower than the limit established by the Resolution (3.7 mg. $\left.\mathrm{L}^{-1}\right)$ for water bodies presenting $\mathrm{pH}$ less than 7.5. However, the maximum admissible concentration for total ammonia is $2.0 \mathrm{mg} . \mathrm{L}^{-1}$ for water bodies presenting $\mathrm{pH}$ in-between 7.5 and 8.0. Thus, Pardo River would not satisfy this condition after the Ibatiba city sewage final disposal for this $\mathrm{pH}$ range.

Pardo River nitrite and nitrate profiles showed an approximately constant growth. This gradual increase in parameters concentration is a consequence of the nitrification process, in which the ammonia oxidizes to nitrite, and the nitrite, in turn, to nitrate. In addition, it was observed that nitrite and nitrate concentrations increased after

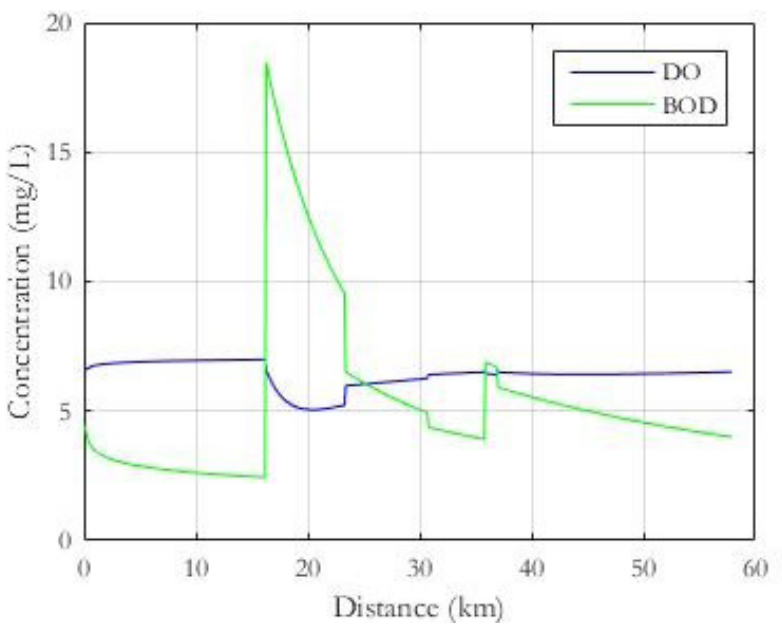

Figure 3. DO and BOD concentration profiles for Pardo River - Scenario 1.

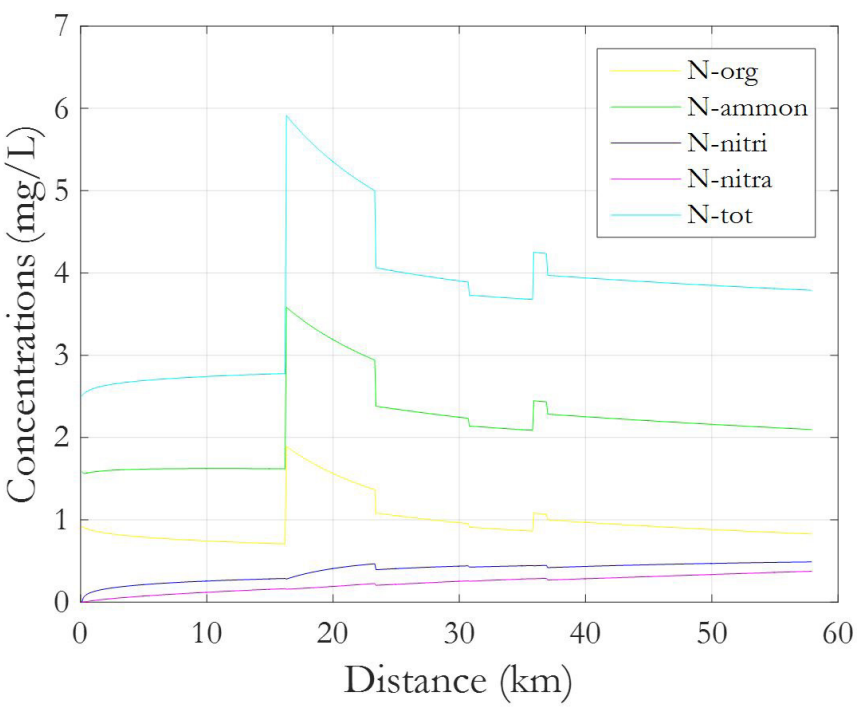

Figure 4. Nitrogen forms concentration profiles for Pardo River - Scenario 1.

inflow from Ibatiba due to the ammoniacal nitrogen present in domestic sewage. São José River produced, by dilution, retraction in the growth of nitrite and nitrate profiles. Along the Pardo River stretch simulated by the water quality model, nitrite concentrations varied from zero to $0.49 \mathrm{mg} . \mathrm{L}^{-1}$, while nitrate concentration varied 
Methodology for minimum nitrogen compounds removal efficiencies estimation and wastewater treatment systems pre-selection: a watershed approach

from zero to $0.38 \mathrm{mg} \cdot \mathrm{L}^{-1}$. Hence, both parameters concentration values were lower than the respective environmental water quality limits. Total nitrogen profile, obtained by the sum of nitrogen forms concentrations, indicated nitrogen decay along the river due to particulate organic nitrogen sedimentation.

Table 5 displays DO, BOD, ammoniacal nitrogen, nitrite and nitrate critical concentrations obtained by water quality simulations for scenario 2. Effluents organic and ammoniacal nitrogen concentrations were assumed equal to zero and $80.0 \mathrm{mg.L} \mathrm{L}^{-1}$, respectively

Unlike what resulted from scenario 1 simulations, Pardo River DO concentrations simulated for scenario 2 did not satisfy the class 2 rivers water quality standard. It was also observed that, for BOD, the critical concentrations obtained for scenario 2 were identical to those obtained for scenario 1. On the other hand, the ammoniacal nitrogen concentrations did not satisfy the environmental quality standard in the Pardo and Pardinho Rivers.

Figure 5 shows the DO and BOD profiles along the Pardo River. Figure 6 presents the nitrogen forms profiles along the watercourse.

Pardo River BOD profile (Figure 5) obtained by water quality model simulation for scenario 2 presented the same behavior observed in the BOD profile obtained for scenario 1. Likewise, the DO profile presented similar behavior to that observed for scenario 1. However, the concentrations were lower and the critical DO concentration (4.90 mg. $\left.\mathrm{L}^{-1}\right)$ was lower than the environmental water quality limit for class 2 rivers. The DO concentrations decrease for scenario 2 was due to the nitrogen demand increase, since this scenario considered the increase of the ammoniacal nitrogen concentration to be oxidized to nitrite and to nitrate.

Pardo River organic nitrogen profile (Figure 6) presented a constant decrease, since in scenario 2 the organic nitrogen concentrations in the raw sewage were considered null. Thus, the final sewage disposal did not contribute to the increase of this constituent concentration in the watercourse. The organic nitrogen concentration in the simulated stretch ranged from $0.92 \mathrm{mg} . \mathrm{L}^{-1}$ to $0.59 \mathrm{mg} . \mathrm{L}^{-1}$, a decrease in concentration that occurred exclusively due to the ammonification process.

Pardo River ammoniacal nitrogen profile obtained for scenario 2 presented concentration values similar to those observed in the profile established for scenario 1 , with concentration peaks at the Ibatiba and Iúna cities domestic sewage discharge points, with decreases in concentration due to the tributaries affluences. The ammoniacal nitrogen concentration peaks estimated by the quality model reached $4.79 \mathrm{mg} . \mathrm{L}^{-1}$ and $2.84 \mathrm{mg} . \mathrm{L}^{-1}$ at the final domestic sewage disposal points. Hence, the ammoniacal nitrogen concentration profile presented peaks that exceeded the water quality limit for any $\mathrm{pH}$ value.

Along the Pardo River nitrite concentrations varied from zero to $0.54 \mathrm{mg} . \mathrm{L}^{-1}$, while nitrate concentrations varied from zero to $0.41 \mathrm{mg} \cdot \mathrm{L}^{-1}$. Thus, all concentration values for both parameters were lower than the respective limits established by CONAMA Resolution 357/2005.

Table 5. Critical Concentrations for Scenario 2.

\begin{tabular}{|c|c|c|c|c|c|}
\hline Watercourse & DO (mg. $\left.\mathrm{L}^{-1}\right)$ & BOD (mg.L $\left.\mathrm{L}^{-1}\right)$ & Ammonia (mg.L-1 & Nitrite (mg. $\left.\mathrm{L}^{-1}\right)$ & Nitrate (mg.. $\left.\mathrm{L}^{-1}\right)$ \\
\hline Pardo River & 4.90 & 18.46 & 4.79 & 0.55 & 0.41 \\
\hline Pardinho River & 5.51 & 14.12 & 3.86 & 0.43 & 0.27 \\
\hline Perdição River & 6.59 & 4.43 & 1.74 & 0.31 & 0.18 \\
\hline Environmental Quality Standard & 5 & 5 & (1) & 1.0 & 10.0 \\
\hline
\end{tabular}

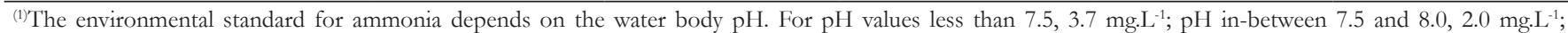
$\mathrm{pH}$ in-between 8.0 and 8.5, $1.0 \mathrm{mg} . \mathrm{L}^{-1} ; \mathrm{pH}$ values higher than $8.5,0.5 \mathrm{mg} . \mathrm{L}^{-1}$.

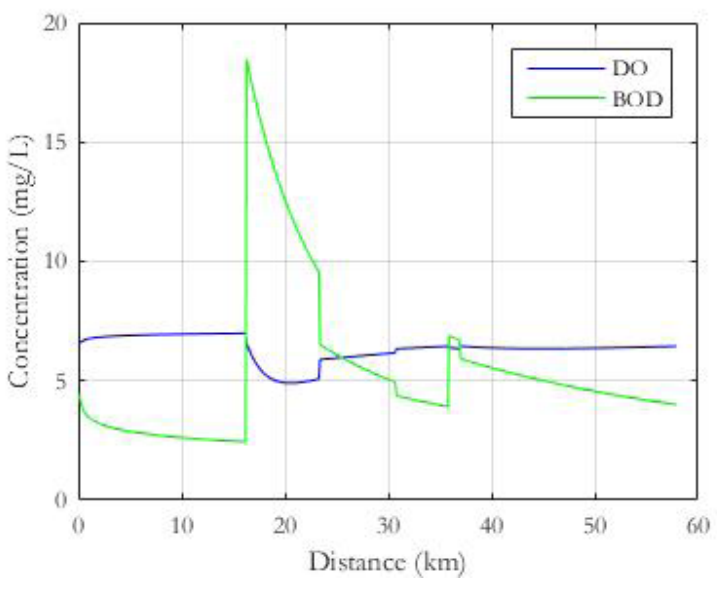

Figure 5. Pardo River DO and BOD concentration profiles Scenario 2.

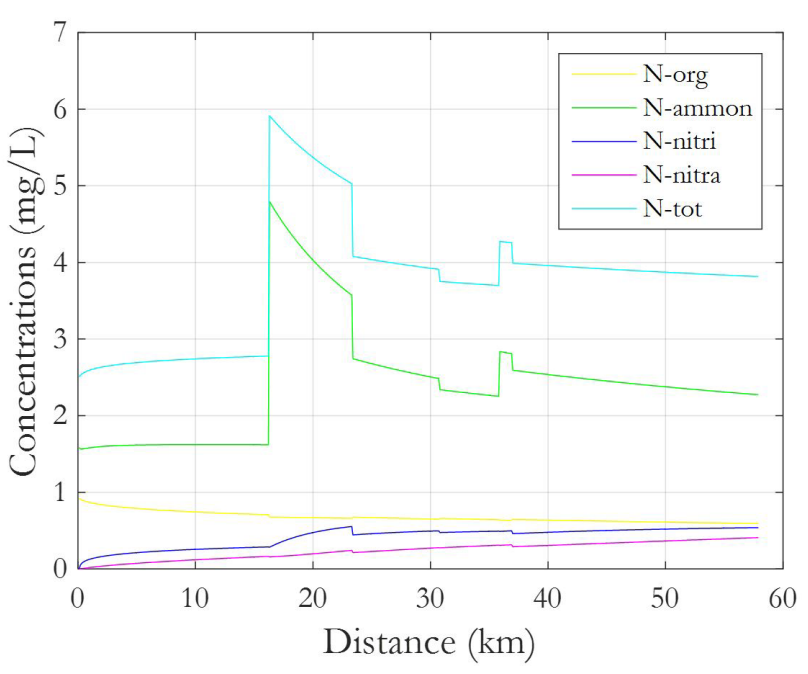

Figure 6. Pardo River concentration profiles for the nitrogen forms - Scenario 2. 


\section{Minimum BOD and nitrogen removal efficiencies}

Table 6 presents the sets of minimum BOD and ammonia removal efficiencies estimated by the simulations for both effluent disposal scenarios and the three discharge conditions analyzed in this study.

From the results analysis, summarized in Table 6 for discharge condition 1, the following observations are considered relevant:

- For the first effluent disposal scenario and $\mathrm{pH}$ values less than or equal to 7.5 , the BOD removal efficiencies were $84 \%$, $81 \%$ and $15 \%$ for Ibatiba, Irupi and Iúna cities, respectively, and null for Santíssima Trindade and Nossa Senhora das Graças towns. Ammonia removal efficiencies were zero for the five locations. For the $\mathrm{pH}$ range from 7.5 to 8.0, the BOD removal efficiencies were $87 \%, 81 \%$ and $13 \%$ for Ibatiba, Irupi and Iúna, respectively, and null for the towns. The ammonia removal efficiencies for Ibatiba, Irupi and Iúna were $80 \%, 71 \%$ and $33 \%$, respectively, and null for Santíssima Trindade and Nossa Senhora das Graças;

- For the second scenario and $\mathrm{pH}$ values less than or equal to 7.5 , the BOD removal efficiencies were the same as those estimated for the same $\mathrm{pH}$ range in the first scenario. However, ammonia removal efficiency were 34\% for Ibatiba, $8 \%$ for Irupi and null for Iúna and both towns. For the $\mathrm{pH}$ range from 7.5 to 8.0, BOD removal efficiencies were
85\% (Ibatiba), 81\% (Irupi) and 15\% (Iúna), while ammonia removal efficiency were 90\% (Ibatiba), 82\% (Irupi) and $43 \%$ (Iuna). For Santíssima Trindade and Nossa Senhora das Graças corresponded zero efficiencies for both BOD and ammonia removals.

The simple verification of Table 6, for discharge condition 2, considering the maximum treatment system effluent BOD concentration 120 mg. $\mathrm{L}^{-1}$, shows that:

- The four simulation sets presented equal BOD removal efficiencies (84\% for Ibatiba, 81\% for Irupi and 70\% for Iúna, Santíssima Trindade and Nossa Senhora das Graças);

- The ammonia removal efficiencies were equal to equal to those obtained for discharge condition 1. The incorporation of the restriction associated to the maximum BOD concentration $120 \mathrm{mg} . \mathrm{L}^{-1}$ showed no effect on the ammonia removal efficiencies.

By examining the results presented in Table 6 , for discharge condition 3 in which the BOD removal efficiencies must be equal to at least $60 \%$, it is observed that:

- The four sets of simulations produced the same BOD removal efficiencies for the watershed cities and towns $84 \%$ for Ibatiba, 81\% for Irupi and 60\% for Iúna, Santíssima Trindade and Nossa Senhora das Graças);

Table 6. Estimated minimum BOD and ammonia removal efficiencies.

\begin{tabular}{|c|c|c|c|c|c|c|c|c|c|c|}
\hline \multirow[b]{2}{*}{$\begin{array}{l}\text { Discharge } \\
\text { Condition }\end{array}$} & \multirow[b]{2}{*}{ Scenario } & \multirow[b]{2}{*}{$\begin{array}{c}\text { Receiving } \\
\text { watercourse } \\
\text { pH }\end{array}$} & \multirow[b]{2}{*}{ Parameter } & \multirow[b]{2}{*}{$\begin{array}{c}\text { Environmental } \\
\text { Quality } \\
\text { Standard } \\
\left(\mathrm{mg.L}^{-1}\right)\end{array}$} & \multicolumn{6}{|c|}{ Efficiency $(\%)$} \\
\hline & & & & & Ibatiba & Irupi & Iúna & $\begin{array}{l}\text { Santíssima } \\
\text { Trindade }\end{array}$ & $\begin{array}{c}\text { Nossa } \\
\text { Senhora } \\
\text { das } \\
\text { Graças }\end{array}$ & $\begin{array}{c}\text { Objective } \\
\text { Function } \\
\text { Value }\end{array}$ \\
\hline \multirow[t]{8}{*}{1} & 1 & $\mathrm{pH} \leq 7.5$ & BOD & 5.0 & 84 & 81 & 15 & 0 & 0 & 180 \\
\hline & & & Ammonia & 3.7 & 0 & 0 & 0 & 0 & 0 & \\
\hline & & $7.5<\mathrm{pH} \leq 8.0$ & BOD & 5.0 & 87 & 81 & 13 & 0 & 0 & 365 \\
\hline & & & Ammonia & 2.0 & 80 & 71 & 33 & 0 & 0 & \\
\hline & 2 & $\mathrm{pH} \leq 7.5$ & BOD & 5.0 & 84 & 81 & 15 & 0 & 0 & 222 \\
\hline & & & Ammonia & 3.7 & 34 & 8 & 0 & 0 & 0 & \\
\hline & & $7.5<\mathrm{pH} \leq 8.0$ & BOD & 5.0 & 85 & 81 & 15 & 0 & 0 & 396 \\
\hline & & & Ammonia & 2.0 & 90 & 82 & 43 & 0 & 0 & \\
\hline \multirow[t]{8}{*}{2} & 1 & $\mathrm{pH} \leq 7.5$ & BOD & 5.0 & 84 & 81 & 70 & 70 & 70 & 375 \\
\hline & & & Ammonia & 3.7 & 0 & 0 & 0 & 0 & 0 & \\
\hline & & $7.5<\mathrm{pH} \leq 8.0$ & BOD & 5.0 & 84 & 81 & 70 & 70 & 70 & 560 \\
\hline & & & Ammonia & 2.0 & 85 & 71 & 29 & 0 & 0 & \\
\hline & 2 & $\mathrm{pH} \leq 7.5$ & BOD & 5.0 & 84 & 81 & 70 & 70 & 70 & 417 \\
\hline & & & Ammonia & 3.7 & 34 & 8 & 0 & 0 & 0 & \\
\hline & & $7.5<\mathrm{pH} \leq 8.0$ & BOD & 5.0 & 84 & 81 & 70 & 70 & 70 & 588 \\
\hline & & & Ammonia & 2.0 & 89 & 81 & 43 & 0 & 0 & \\
\hline \multirow[t]{8}{*}{3} & 1 & $\mathrm{pH} \leq 7.5$ & BOD & 5.0 & 81 & 60 & 60 & 60 & 81 & 345 \\
\hline & & & Ammonia & 3.7 & 0 & 0 & 0 & 0 & 0 & \\
\hline & & $7.5<\mathrm{pH} \leq 8.0$ & BOD & 5.0 & 81 & 60 & 60 & 60 & 81 & 529 \\
\hline & & & Ammonia & 2.0 & 71 & 30 & 0 & 0 & 71 & \\
\hline & 2 & $\mathrm{pH} \leq 7.5$ & BOD & 5.0 & 81 & 60 & 60 & 60 & 81 & 387 \\
\hline & & & Ammonia & 3.7 & 8 & 0 & 0 & 00 & 8 & \\
\hline & & $7.5<\mathrm{pH} \leq 8.0$ & BOD & 5.0 & 81 & 60 & 60 & 60 & 81 & 559 \\
\hline & & & Ammonia & 2.0 & 82 & 42 & 0 & 0 & 82 & \\
\hline
\end{tabular}


Methodology for minimum nitrogen compounds removal efficiencies estimation and wastewater treatment systems pre-selection: a watershed approach

- The ammonia removal efficiencies presented values equal to those obtained when there was no effluent quality standard imposition. Thus, it was found that the incorporation of the restriction associated with the minimum effluent BOD removal efficiency $60 \%$ had no effect on the removal ammonia efficiencies.

It is important to note that effluent quality standards adoption or minimum treatment levels imposition can lead to significant increases in BOD removal efficiencies, condition that was not reproduced for the minimum ammonia removal levels. In this context, treatment plants can be overestimated and lead to adoption of more robust treatment systems presenting higher costs, thus contributing to inadequate financial management of the generally limited resources available for WWTP implementation and operation.

Pardo River BOD, DO and ammonia concentration profiles were drawn from the estimated efficiencies set for discharge condition 1 , scenario 1 and waters presenting $\mathrm{pH}$ from 7.5 to 8.0 as presented in the Figures 7, 8 and 9, respectively. Analyzing these Figures it is possible to observe that the estimated BOD and ammonia removal efficiencies allowed these constituents concentrations to reach (without exceeding) the environmental quality standard. Additionally, the DO concentrations remained above the minimum value established by the environmental quality standard, showing that the estimated efficiencies values were the smallest possible.

\section{Wastewater treatment systems pre-selection}

Treatment systems pre-selection was carried out from the results of three discharge simulations conditions: a) rivers self-purification capacities consideration for effluents assimilation (C1); b) treated sewage BOD concentration $120 \mathrm{mg} \cdot \mathrm{L}^{-1}$ (C2) and c) minimum BOD removal efficiency $60 \%$ (C3). Tables 7 to 10 present treatment systems pre-selection results for each Pardo River watershed sewage disposal site.

From Tables 7 to 10 analysis, the following observations are considered:

- The combined use of the water quality model and the optimization technique indicated the highest removal efficiencies of both BOD and ammonia for the sewage generated at Ibatiba and Irupi cities, regardless of the final effluent disposal condition evaluated. The minimum BOD removal efficiencies estimated for the two cities were above $80 \%$, limiting the initial set of treatment alternatives. No treatment alternative was pre-selected for the said locations from the treatment alternatives set and treatment systems efficiencies ranges assumed in this work due to the high ammonia removal requirement for the simulations associated to the second effluent disposal scenario for water $\mathrm{pH}$ values from 7.5 to 8.0;

- The pre-selected treatment alternatives for Ibatiba and Irupi varied only according to the water $\mathrm{pH}$ range and scenarios analyzed, regardless of the eventual treated effluents quality standard imposition;

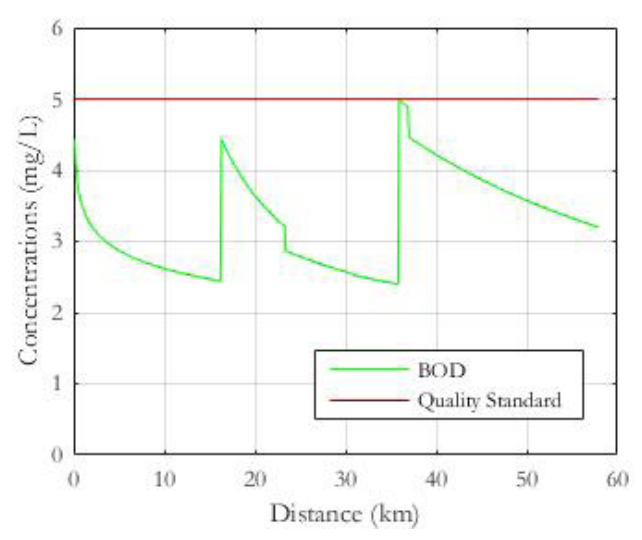

Figure 7. Pardo River BOD profile for discharge condition 1, scenario 1 and $\mathrm{pH}$ values between 7.5 and 8.0.

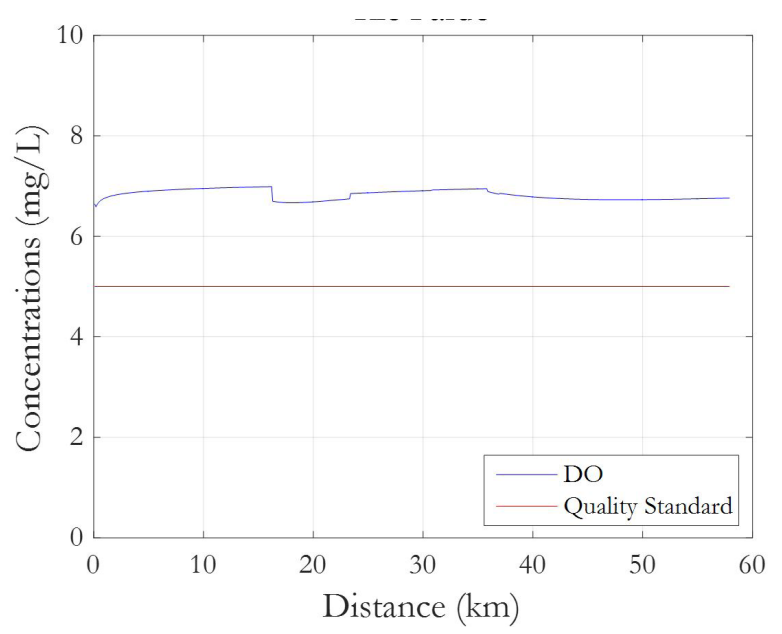

Figure 8. Pardo River DO profile for discharge condition 1, scenario 1 and $\mathrm{pH}$ values between 7.5 and 8.0.

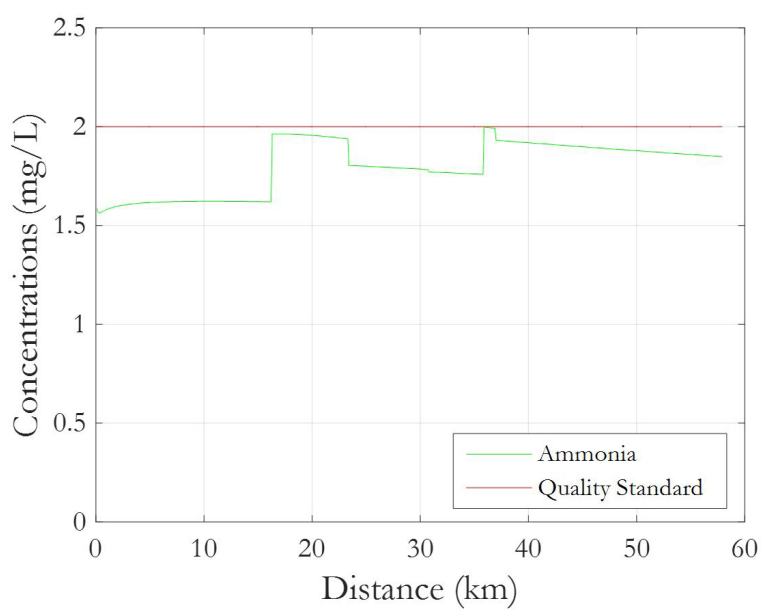

Figure 9. Pardo River ammonia profile for discharge condition 1, scenario 1 and $\mathrm{pH}$ values between 7.5 and 8.0.

- The largest set of pre-selected treatment alternatives was established for Iúna city, although the lowest BOD and ammonia removal efficiencies were estimated for Santíssima Trindade and Nossa Senhora das Graças towns. This result 
Table 7. Pre-selected treatment alternatives for Ibatiba city.

\begin{tabular}{|c|c|c|c|c|c|c|c|c|c|c|c|}
\hline \multicolumn{4}{|c|}{ Discharge condition 1} & \multicolumn{4}{|c|}{ Discharge condition 2} & \multicolumn{4}{|c|}{ Discharge condition 3} \\
\hline Scen & $\operatorname{ario} 1$ & Scen & & Scen & & Scen & & Scen & & Scen & \\
\hline 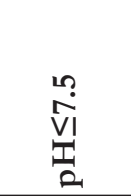 & 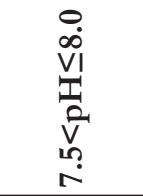 & 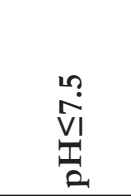 & 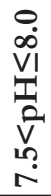 & $\begin{array}{l}n_{2} \\
\frac{1}{V_{1}} \\
\frac{1}{2}\end{array}$ & 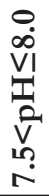 & 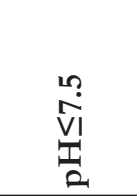 & 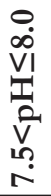 & 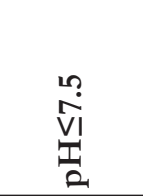 & 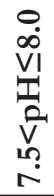 & $\begin{array}{l}n \\
\text { VI } \\
\text { II } \\
2\end{array}$ & 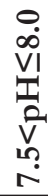 \\
\hline $\begin{array}{l}\text { A10. A14, } \\
\text { A16, A18, } \\
\text { A19, A21, } \\
\text { A22, A27, } \\
\text { A28, A29, } \\
\text { A30, A31, } \\
\text { A32, A33, } \\
\text { A34, A35, } \\
\text { A36, A37 }\end{array}$ & $\begin{array}{l}\text { A27, A28, } \\
\text { A29, A30, } \\
\text { A31, A32, } \\
\text { A35, A36 }\end{array}$ & $\begin{array}{c}\text { A10. A14, } \\
\text { A16, A18, } \\
\text { A19, A21, } \\
\text { A27, A28, } \\
\text { A29, A30, } \\
\text { A31, A32, } \\
\text { A33, A34, } \\
\text { A35, A36, } \\
\text { A37 }\end{array}$ & - & $\begin{array}{l}\text { A10. A14, } \\
\text { A16, A18, } \\
\text { A19, A21, } \\
\text { A22, A27, } \\
\text { A28, A29, } \\
\text { A30, A31, } \\
\text { A32, A33, } \\
\text { A34, A35, } \\
\text { A36, A37 }\end{array}$ & - & $\begin{array}{c}\text { A10. A14, } \\
\text { A16, A18, } \\
\text { A19, A21, } \\
\text { A27, A28, } \\
\text { A29, A30, } \\
\text { A31, A32, } \\
\text { A33, A34, } \\
\text { A35, A36, } \\
\text { A37 }\end{array}$ & - & $\begin{array}{l}\text { A10. A14, } \\
\text { A16, A18, } \\
\text { A19, A21, } \\
\text { A22, A27, } \\
\text { A28, A29, } \\
\text { A30, A31, } \\
\text { A32, A33, } \\
\text { A34, A35, } \\
\text { A36, A37 }\end{array}$ & - & $\begin{array}{c}\text { A10. A14, } \\
\text { A16, A18, } \\
\text { A19, A21, } \\
\text { A27, A28, } \\
\text { A29, A30, } \\
\text { A31, A32, } \\
\text { A33, A34, } \\
\text { A35, A36, } \\
\text { A37 }\end{array}$ & - \\
\hline
\end{tabular}

Table 8. Pre-selected treatment alternatives for Irupi city.

\begin{tabular}{|c|c|c|c|c|c|c|c|c|c|c|c|}
\hline \multicolumn{4}{|c|}{ Discharge condition 1} & \multicolumn{4}{|c|}{ Discharge condition 2} & \multicolumn{4}{|c|}{ Discharge condition 3} \\
\hline Scen & $\operatorname{ario} 1$ & Scen & & Scen & ario 1 & Scen & & Scen & ario 1 & Scen & \\
\hline 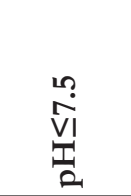 & 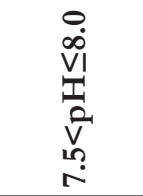 & 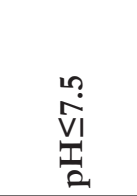 & 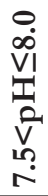 & 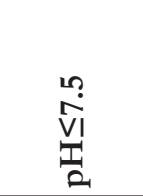 & 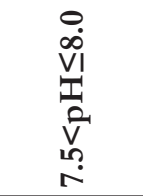 & 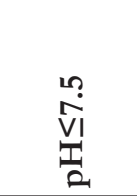 & 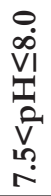 & 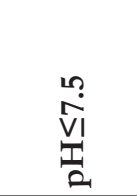 & 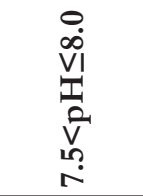 & $\begin{array}{l}n \\
\stackrel{n}{V} \\
\text { VI } \\
2\end{array}$ & 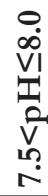 \\
\hline $\begin{array}{c}\text { A08, A09, } \\
\text { A10, A14, } \\
\text { A15, A16, } \\
\text { A17, A18, } \\
\text { A19, A20, } \\
\text { A21, A22, } \\
\text { A23, A26, } \\
\text { A27, A28, } \\
\text { A29, A30, } \\
\text { A31, A32, } \\
\text { A33, A34, } \\
\text { A35, A36, } \\
\text { A37 }\end{array}$ & $\begin{array}{c}\text { A } 09, \text { A27, } \\
\text { A28, A29, } \\
\text { A30, A31, } \\
\text { A32, A33, } \\
\text { A35, A36, } \\
\text { A37 }\end{array}$ & $\begin{array}{c}\text { A08, A09, } \\
\text { A10, A14, } \\
\text { A15, A16, } \\
\text { A17, A18, } \\
\text { A19, A20, } \\
\text { A21, A22, } \\
\text { A23, A26, } \\
\text { A27, A28, } \\
\text { A29, A30, } \\
\text { A31, A32, } \\
\text { A33, A34, } \\
\text { A35, A36, } \\
\text { A37 }\end{array}$ & - & $\begin{array}{c}\text { A08, A09, } \\
\text { A10, A14, } \\
\text { A15, A16, } \\
\text { A17, A18, } \\
\text { A19, A20, } \\
\text { A21, A22, } \\
\text { A23, A26, } \\
\text { A27, A28, } \\
\text { A29, A30, } \\
\text { A31, A32, } \\
\text { A33, A34, } \\
\text { A35, A36, } \\
\text { A37 }\end{array}$ & $\begin{array}{c}\text { A } 09, \text { A27, } \\
\text { A28, A29, } \\
\text { A30, A31, } \\
\text { A32, A33, } \\
\text { A35, A36, } \\
\text { A37 }\end{array}$ & $\begin{array}{c}\text { A08, A09, } \\
\text { A10, A14, } \\
\text { A15, A16, } \\
\text { A17, A18, } \\
\text { A19, A20, } \\
\text { A21, A22, } \\
\text { A23, A26, } \\
\text { A27, A28, } \\
\text { A29, A30, } \\
\text { A31, A32, } \\
\text { A33, A34, } \\
\text { A35, A36, } \\
\text { A37 }\end{array}$ & - & $\begin{array}{c}\text { A08, A09, } \\
\text { A10, A14, } \\
\text { A15, A16, } \\
\text { A17, A18, } \\
\text { A19, A20, } \\
\text { A21, A22, } \\
\text { A23, A26, } \\
\text { A27, A28, } \\
\text { A29, A30, } \\
\text { A31, A32, } \\
\text { A33, A34, } \\
\text { A35, A36, } \\
\text { A37 }\end{array}$ & $\begin{array}{c}\text { A } 09, \text { A27, } \\
\text { A28, A29, } \\
\text { A30, A31, } \\
\text { A32, A33, } \\
\text { A35, A36, } \\
\text { A37 }\end{array}$ & $\begin{array}{c}\text { A } 08, \text { A } 09, \\
\text { A10, A14, } \\
\text { A15, A16, } \\
\text { A17, A18, } \\
\text { A19, A20, } \\
\text { A21, A22, } \\
\text { A23, A26, } \\
\text { A27, A28, } \\
\text { A29, A30, } \\
\text { A31, A32, } \\
\text { A33, A34, } \\
\text { A35, A36, } \\
\text { A37 }\end{array}$ & - \\
\hline
\end{tabular}

Table 9. Pre-selected treatment alternatives for Iúna city.

\begin{tabular}{|c|c|c|c|c|c|c|c|c|c|c|c|}
\hline \multicolumn{4}{|c|}{ Discharge condition 1} & \multicolumn{4}{|c|}{ Discharge condition 2} & \multicolumn{4}{|c|}{ Discharge condition 3} \\
\hline \multicolumn{2}{|c|}{ Scenario 1} & \multicolumn{2}{|c|}{ Scenario 2} & \multicolumn{2}{|c|}{ Scenario 1} & \multicolumn{2}{|c|}{$\begin{array}{c}\text { Scenario } 2 \\
\end{array}$} & \multicolumn{2}{|c|}{ Scenario 1} & \multicolumn{2}{|c|}{ Scenario 2} \\
\hline 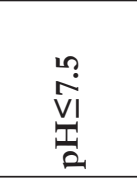 & 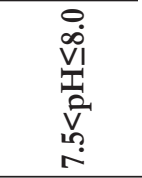 & 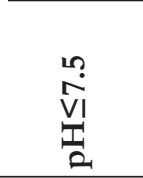 & 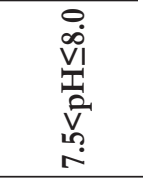 & 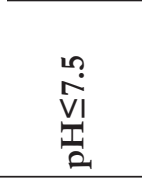 & 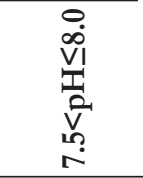 & 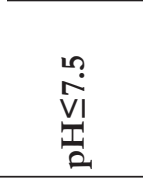 & 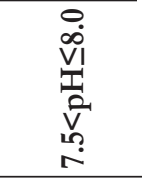 & $\begin{array}{l}\stackrel{n}{r} \\
\text { VI } \\
\text { II } \\
\stackrel{1}{2}\end{array}$ & 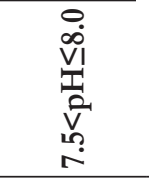 & $\begin{array}{l}n \\
\hat{n} \\
\text { VI } \\
\frac{1}{2}\end{array}$ & 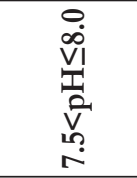 \\
\hline $\begin{array}{l}\text { A01, A02, } \\
\text { A03, A04, } \\
\text { A05, A06, } \\
\text { A07, A08, } \\
\text { A09, A10, } \\
\text { A14, A15, } \\
\text { A16, A17, } \\
\text { A18, A19, } \\
\text { A20, A21, } \\
\text { A22, A23, } \\
\text { A24, A25, } \\
\text { A26, A27, } \\
\text { A28, A29, } \\
\text { A30, A31, } \\
\text { A32, A33, } \\
\text { A34, A35, } \\
\text { A36, A37 }\end{array}$ & $\begin{array}{l}\text { A04, A05, } \\
\text { A08, A09, } \\
\text { A10, A14, } \\
\text { A15, A16, } \\
\text { A17, A18, } \\
\text { A19, A20, } \\
\text { A21, A23, } \\
\text { A26, A27, } \\
\text { A28, A29, } \\
\text { A30, A31, } \\
\text { A32, A33, } \\
\text { A34, A35, } \\
\text { A36, A37 }\end{array}$ & $\begin{array}{l}\text { A01, A02, } \\
\text { A03, A04, } \\
\text { A05, A06, } \\
\text { A07, A08, } \\
\text { A09, A10, } \\
\text { A14, A15, } \\
\text { A16, A17, } \\
\text { A18, A19, } \\
\text { A20, A21, } \\
\text { A22, A23, } \\
\text { A24, A25, } \\
\text { A26, A27, } \\
\text { A28, A29, } \\
\text { A30, A31, } \\
\text { A32, A33, } \\
\text { A34, A35, } \\
\text { A36, A37 }\end{array}$ & $\begin{array}{l}\text { A04, A05, } \\
\text { A08, A09, } \\
\text { A10, A14, } \\
\text { A15, A16, } \\
\text { A17, A18, } \\
\text { A19, A20, } \\
\text { A21, A23, } \\
\text { A26, A27, } \\
\text { A28, A29, } \\
\text { A30, A31, } \\
\text { A32, A33, } \\
\text { A34, A35, } \\
\text { A36, A37 }\end{array}$ & $\begin{array}{l}\text { A04, A05, } \\
\text { A06, A07, } \\
\text { A08, A09, } \\
\text { A10, A14, } \\
\text { A15, A16, } \\
\text { A18, A19, } \\
\text { A20, A21, } \\
\text { A22, A23, } \\
\text { A24, A25, } \\
\text { A26, A27, } \\
\text { A28, A29, } \\
\text { A30, A31, } \\
\text { A32, A33, } \\
\text { A34, A35, } \\
\text { A36, A37 }\end{array}$ & $\begin{array}{l}\text { A04, A05, } \\
\text { A06, A07, } \\
\text { A08, A09, } \\
\text { A10, A14, } \\
\text { A15, A16, } \\
\text { A18, A19, } \\
\text { A20, A21, } \\
\text { A22, A23, } \\
\text { A24, A25, } \\
\text { A26, A27, } \\
\text { A28, A29, } \\
\text { A30, A31, } \\
\text { A32, A33, } \\
\text { A34, A35, } \\
\text { A36, A37 }\end{array}$ & $\begin{array}{l}\text { A04, A05, } \\
\text { A06, A07, } \\
\text { A08, A09, } \\
\text { A10, A14, } \\
\text { A15, A16, } \\
\text { A18, A19, } \\
\text { A20, A21, } \\
\text { A22, A23, } \\
\text { A24, A25, } \\
\text { A26, A27, } \\
\text { A28, A29, } \\
\text { A30, A31, } \\
\text { A32, A33, } \\
\text { A34, A35, } \\
\text { A36, A37 }\end{array}$ & $\begin{array}{c}\text { A04, A05, } \\
\text { A08, A09, } \\
\text { A10, A14, } \\
\text { A15, A16, } \\
\text { A18, A19, } \\
\text { A20, A21, } \\
\text { A23, A26, } \\
\text { A27, A28, } \\
\text { A29, A30, } \\
\text { A31, A32, } \\
\text { A33, A34, } \\
\text { A35, A36, } \\
\text { A37 }\end{array}$ & $\begin{array}{l}\text { A03, A04, } \\
\text { A05, A06, } \\
\text { A07, A08, } \\
\text { A09, A10, } \\
\text { A14, A15, } \\
\text { A16, A17, } \\
\text { A18, A19, } \\
\text { A20, A21, } \\
\text { A22, A23, } \\
\text { A24, A25, } \\
\text { A26, A27, } \\
\text { A28, A29, } \\
\text { A30, A31, } \\
\text { A32, A33, } \\
\text { A34, A35, } \\
\text { A36, A37 }\end{array}$ & $\begin{array}{l}\text { A03, A04, } \\
\text { A05, A06, } \\
\text { A07, A08, } \\
\text { A09, A10, } \\
\text { A14, A15, } \\
\text { A16, A17, } \\
\text { A18, A19, } \\
\text { A20, A21, } \\
\text { A22, A23, } \\
\text { A24, A25, } \\
\text { A26, A27, } \\
\text { A28, A29, } \\
\text { A30, A31, } \\
\text { A32, A33, } \\
\text { A34, A35, } \\
\text { A36, A37 }\end{array}$ & $\begin{array}{l}\text { A03, A04, } \\
\text { A05, A06, } \\
\text { A07, A08, } \\
\text { A09, A10, } \\
\text { A14, A15, } \\
\text { A16, A17, } \\
\text { A18, A19, } \\
\text { A20, A21, } \\
\text { A22, A23, } \\
\text { A24, A25, } \\
\text { A26, A27, } \\
\text { A28, A29, } \\
\text { A30, A31, } \\
\text { A32, A33, } \\
\text { A34, A35, } \\
\text { A36, A37 }\end{array}$ & $\begin{array}{l}\text { A04, A05, } \\
\text { A08, A09, } \\
\text { A10, A14, } \\
\text { A15, A16, } \\
\text { A17, A18, } \\
\text { A19, A20, } \\
\text { A21, A23, } \\
\text { A26, A27, } \\
\text { A28, A29, } \\
\text { A30, A31, } \\
\text { A32, A33, } \\
\text { A34, A35, } \\
\text { A36, A37 }\end{array}$ \\
\hline
\end{tabular}


Methodology for minimum nitrogen compounds removal efficiencies estimation and wastewater treatment systems pre-selection: a watershed approach

Table 10. Pre-selected treatment alternatives for Santíssima Trindade and Nossa Senhora das Graças towns.

\begin{tabular}{|c|c|c|c|c|c|c|c|c|c|c|c|}
\hline \multicolumn{4}{|c|}{ Discharge condition 1} & \multicolumn{4}{|c|}{ Discharge condition 2} & \multicolumn{4}{|c|}{ Discharge condition 3} \\
\hline \multicolumn{2}{|c|}{ Scenario 1} & \multicolumn{2}{|c|}{ Scenario 2} & \multicolumn{2}{|c|}{ Scenario 1} & \multicolumn{2}{|c|}{ Scenario 2} & \multicolumn{2}{|c|}{ Scenario 1} & \multicolumn{2}{|c|}{ Scenario 2} \\
\hline 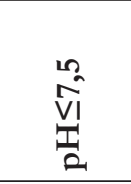 & 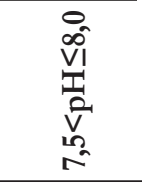 & $\begin{array}{l}n_{2} \\
\hat{v} \\
\text { vin } \\
2\end{array}$ & 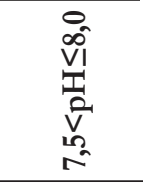 & $\begin{array}{l}n_{2} \\
\hat{V}^{\prime} \\
\text { II } \\
\text { L }\end{array}$ & 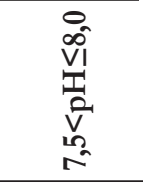 & $\begin{array}{l}n_{2} \\
\hat{V} \\
\frac{1}{2} \\
2\end{array}$ & 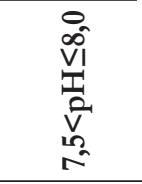 & $\begin{array}{l}n_{2} \\
\stackrel{1}{V_{1}} \\
\frac{1}{2}\end{array}$ & 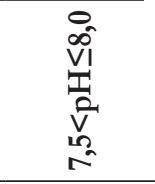 & 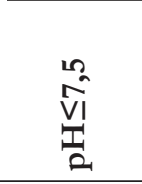 & 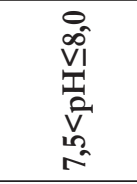 \\
\hline $\begin{array}{c}\text { A01, A02, } \\
\text { A03, A04, } \\
\text { A05, A08, } \\
\text { A10, A11, } \\
\text { A12, A13, } \\
\text { A14, A15, } \\
\text { A16, A17, } \\
\text { A20, A21, } \\
\text { A23, A26, } \\
\text { A33, A34, } \\
\text { A37 }\end{array}$ & $\begin{array}{c}\text { A01, A02, } \\
\text { A03, A04, } \\
\text { A05, A08, } \\
\text { A10, A11, } \\
\text { A12, A13, } \\
\text { A14, A15, } \\
\text { A16, A17, } \\
\text { A20, A21, } \\
\text { A23, A26, } \\
\text { A33, A34, } \\
\text { A37 }\end{array}$ & $\begin{array}{c}\text { A03, A04, } \\
\text { A05, A08, } \\
\text { A10, A11, } \\
\text { A12, A13, } \\
\text { A14, A15, } \\
\text { A16, A17, } \\
\text { A20, A21, } \\
\text { A23, A26, } \\
\text { A33, A34, } \\
\text { A37 }\end{array}$ & $\begin{array}{c}\text { A03, A04, } \\
\text { A05, A08, } \\
\text { A10, A11, } \\
\text { A12, A13, } \\
\text { A14, A15, } \\
\text { A16, A17, } \\
\text { A20, A21, } \\
\text { A23, A26, } \\
\text { A33, A34, } \\
\text { A37 }\end{array}$ & $\begin{array}{c}\text { A04, A05, } \\
\text { A08, A10, } \\
\text { A11, A12, } \\
\text { A13, A14, } \\
\text { A15, A16, } \\
\text { A20, A21, } \\
\text { A23, A26, } \\
\text { A33, A34, } \\
\text { A37 }\end{array}$ & $\begin{array}{c}\text { A04, A05, } \\
\text { A08, A10, } \\
\text { A11, A12, } \\
\text { A13, A14, } \\
\text { A15, A16, } \\
\text { A20, A21, } \\
\text { A23, A26, } \\
\text { A33, A34, } \\
\text { A37 }\end{array}$ & $\begin{array}{c}\text { A04, A05, } \\
\text { A08, A10, } \\
\text { A11, A12, } \\
\text { A13, A14, } \\
\text { A15, A16, } \\
\text { A20, A21, } \\
\text { A23, A26, } \\
\text { A33, A34, } \\
\text { A37 }\end{array}$ & $\begin{array}{c}\text { A04, A05, } \\
\text { A08, A10, } \\
\text { A11, A12, } \\
\text { A13, A14, } \\
\text { A15, A16, } \\
\text { A20, A21, } \\
\text { A23, A26, } \\
\text { A33, A34, } \\
\text { A37 }\end{array}$ & $\begin{array}{c}\text { A03, A04, } \\
\text { A05, A08, } \\
\text { A10, A11, } \\
\text { A12, A13, } \\
\text { A14, A15, } \\
\text { A16, A17, } \\
\text { A20, A21, } \\
\text { A23, A26, } \\
\text { A33, A34, } \\
\text { A37 }\end{array}$ & $\begin{array}{c}\text { A03, A04, } \\
\text { A05, A08, } \\
\text { A10, A11, } \\
\text { A12, A13, } \\
\text { A14, A15, } \\
\text { A16, A17, } \\
\text { A20, A21, } \\
\text { A23, A26, } \\
\text { A33, A34, } \\
\text { A37 }\end{array}$ & $\begin{array}{c}\text { A03, A04, } \\
\text { A05, A08, } \\
\text { A10, A11, } \\
\text { A12, A13, } \\
\text { A14, A15, } \\
\text { A16, A17, } \\
\text { A20, A21, } \\
\text { A23, A26, } \\
\text { A33, A34, } \\
\text { A37 }\end{array}$ & $\begin{array}{c}\text { A03, A04, } \\
\text { A05, A08, } \\
\text { A10, A11, } \\
\text { A12, A13, } \\
\text { A14, A15, } \\
\text { A16, A17, } \\
\text { A20, A21, } \\
\text { A23, A26, } \\
\text { A33, A34, } \\
\text { A37 }\end{array}$ \\
\hline
\end{tabular}

was due to the fact that the pre-selection of the alternatives for these towns did not consider the choice of mechanized systems that demand power for aeration, thus eliminating 16 out of the 37 treatment systems considered. For Iúna, the adopted criteria related with the non-selection of systems associated with final soil disposal in the soil eliminated only 3 out of the 37 treatment systems;

The pre-selected treatment alternatives sets for Santíssima Trindade and Nossa Senhora das Graças towns were identical for all final sewage disposal conditions evaluated.

- The treatment systems pre-selection for the first effluents final disposal condition for Iúna, Santíssima Trindade, and Nossa Senhora das Graças was the one that indicated the greater amount of alternatives, since when considering the river self-purification capacity for effluent dilution the lowest BOD removal efficiencies and zero or very small ammonia removal efficiencies were obtained. The final discharge conditions 2 and 3 cause significant increase in the BOD removal efficiency, leading to more robust treatment systems pre-selection;

- For Ibatiba and Irupi, the pre-selected treatment systems for each final effluent discharge condition were identical for the three conditions analyzed, excepting the pre-selected systems for Ibatiba for the first effluent discharge condition and water presenting $\mathrm{pH}$ values from 7.5 to 8.0. In this context, water bodies self-purification capacities consideration or treated effluents quality standards imposition did not influence pre-selection;

- The scenario that considered higher ammonia inflow, considering complete ammonification before sewage discharge in the water bodies, did not produce differences in the pre-selected treatment alternatives for $\mathrm{pH}$ values equal to or lower than 7.5 , when compared to the scenario that considered the maximum organic nitrogen and ammonia concentration values usually observed in raw sewage;

- Santíssima Trindade and Nossa Senhora das Graças towns presented the same pre-selected treatment systems for different $\mathrm{pH}$ ranges. Ibatiba, Irupi and Iúna cities presented smaller treatment systems set for the $\mathrm{pH}$ range from 7.5 to 8.0 than for the $\mathrm{pH}$ range less than or equal to 7.5. This aspect evidences the fact that for higher water watercourses $\mathrm{pH}$ values effluents treatment systems need to be more efficient towards ammonia removal, due to the toxic behavior of this constituent. Although the ammonia compounds toxicity in freshwater bodies is influenced by temperature, salinity and $\mathrm{pH}$ values (REIS; MENDONÇA, 2009), the present study considered only the effect of $\mathrm{pH}$, since the environmental quality standards established in Brazil did not include temperature and/or salinity effects.

\section{CONCLUSIONS}

From water quality modeling combined with an optimization technique, aiming at BOD and nitrogen compounds minimum treatment efficiencies determination and sewage treatment systems pre-selection within a river basin, the main conclusions can be summarized as follows:

- The DO concentrations were in accordance with the environmental quality standard when considering the disposition of raw sewage presenting organic nitrogen concentration $30 \mathrm{mg} . \mathrm{L}^{-1}$ and ammonia concentration $50 \mathrm{mg} . \mathrm{L}^{-1}$ (scenario 1). The environmental standards for ammonia have been respected for waters presenting $\mathrm{pH}$ equal to or less than 7.5. Correspondingly, the environmental nitrite and nitrate parameters quality standards were always respected. However, the BOD environmental quality standard was disrespected in Pardo and Pardinho Rivers stretches;

- Considering the raw sewage disposal after complete ammonification, that is zero organic nitrogen concentration and ammonia concentration $80 \mathrm{mg} \cdot \mathrm{L}^{-1}$ (scenario 2), the DO concentrations in the Pardo River respected the environmental quality standard. The standard set for BOD was violated in Pardo and Pardinho Rivers stretches. For ammonia, both rivers presented concentrations higher 
than the environmental limit for any $\mathrm{pH}$ value. On the other hand, nitrite and nitrate parameters concentrations respected the environmental quality standards;

- In simulations where self-purification capacity for the assimilation of the effluents was considered without effluents quality standard imposition (discharge condition 1) BOD removal efficiencies ranged from zero to $87 \%$. For discharge conditions 2 and 3, where effluents quality standards or minimum treatment efficiencies were considered, BOD removal efficiencies ranged from 60 to $84 \%$;

- Due to the ammonia toxicity increase with $\mathrm{pH}$ elevation, treatment systems need to be more effluents ammonia compounds removal efficient for alkaline water. Thus, the diversity of pre-selected treatment systems was greater in those simulation conditions for which $\mathrm{pH}$ values equal to or less than 7.5 were assumed. Therefore, except in conditions for which watercourse $\mathrm{pH}$ values are known and stable, the consideration of higher $\mathrm{pH}$ values, according to $\mathrm{pH}$ ranges established by the environmental quality standard, in sewage treatment plants selection processes conducts to better aquatic environment quality;

- Considering rivers self-purification capacities, without effluents quality standards imposition, raw sewage that present the different nitrogen forms and water $\mathrm{pH}$ values from 7.5 to 8.0 (higher $\mathrm{pH}$ values for which the present study boundary condition allowed treatment systems pre-selection), the treatment systems pre-selected for Ibatiba (most populated city located in the study area) were activated sludges and their variations, and submerged aerated biofilter with nitrification or biological nitrogen removal. Under the same analysis conditions, simpler systems, such as primary treatment with septic tanks, stabilization pond systems variations, UASB reactors in association with anaerobic filter, high load percolating biological filter, polishing or surface runoff pond, biological filters and biodiscs were pre-selected for Santíssima Trindade and Nossa Senhora das Graças towns.

\section{ACKNOWLEDGEMENTS}

To Coordenação de Aperfeiçoamento Pessoal de Nível Superior (CAPES) for granting scholarship to this article first author.

\section{REFERENCES}

AGUIRRE JÚNIOR, J. C. Plano diretor de recursos hídricos das bacias do leste. Belo Horizonte: Fundação Rural Mineira de Colonização e Desenvolvimento Agrário, 2000.

ALBERTIN, L. L. Técnica de gerenciamento da qualidade hidrica superficial baseada na otimização multiobjetivo. 2008. 191 f. Tese (Doutorado em Hidráulica e Saneamento) - Escola de Engenharia de São Carlos, Universidade de São Paulo, São Carlos, 2008.
ANDRADE, L. N.; MAURI, R. G.; MENDONÇA, A. S. F. A general multiobjective model and a simulated annealing algorithm for waste-load allocation. Journal of Water Resources Planning and Management, v. 139, n. 3, p. 339-344, 2013. http://dx.doi.org/10.1061/ (ASCE)WR.1943-5452.0000257.

BOWIE, G. L.; MILLS, W. B.; PORCELLA, D. B.; CAMPBELL, C. L.; PAGENKOPF, J. R.; RUPP, G. L.; JOHNSON, K. M.; CHAN, P. W. H.; GHERINI, S. A. Technical report EPA-600/3-85040: rates, constants, and kinetics formulations in surface water quality modeling. 2nd ed. Washington: USEPA, 1985.

BRASIL. Resolução CONAMA no 357, de 17 de março de 2005. Dispõe sobre a classificação dos corpos de água e diretrizes ambientais para o seu enquadramento, bem como estabelece as condições e padrões de lançamento de efluentes, e dá outras providências. Diário Oficial [da] República Federativa do Brasil, Brasília, DF, 17 mar. 2005.

BRASIL. Resolução CONAMA nº 430, de 13 de maio de 2011. Dispõe sobre as condições e padrões de lançamento de efluentes, complementa e altera a Resolução n ${ }^{\circ}$ 357, de 17 de março de 2005, do Conselho Nacional do Meio Ambiente - CONAMA. Diário Oficial [da] República Federativa do Brasil, Brasília, DF, 13 maio 2011.

BRINGER, L. M.; REIS, J. A. T.; MENDONÇA, A. S. F. Wastewater treatment systems selection inside watersheds by using multiobjective analysis. Revista Brasileira de Recursos Hídricos, v. 23, p. e22, 2018. http://dx.doi.org/10.1590/2318-0331.231820170140.

CALMON, A. P. S.; SOUZA, J. C. S.; REIS, J. A. T.; MENDONÇA, A. S. F. Uso combinado de curvas de permanência de qualidade e modelagem da autodepuração como ferramenta para suporte ao processo de enquadramento de cursos d'água superficiais. Revista Brasileira de Recursos Hídricos, v. 21, n. 1, p. 118-133, 2016. http:/ / dx.doi.org/10.21168/rbrh.v21n1.p118-133.

CHO, J. H.; SUNG, K. S.; HA, S. R. A river water quality management model for optimising regional wastewater treatment using a genetic algorithm. Journal of Environmental Management, v. 73, n. 3, p. 229242, 2004. http://dx.doi.org/10.1016/j.jenvman.2004.07.004. PMid:15474740.

FANTIN, L. L. D. O.; REIS, J. A. T.; MENDONÇA, A. S. F. Proposal of a methodology for pre-selection of sewage treatment systems within watersheds. Revista Brasileira de Recursos Hídricos, v. 22, p. e12, 2017. http://dx.doi.org/10.1590/2318-0331.011716079.

FEIZI ASHTIANI, E.; NIKSOKHAN, M. H.; ARDESTANI, M. Multi-objective waste load allocation in river system by MOPSO algorithm. International Journal of Environmental of Research, v. 9, n. 1, p. 69-76, 2015.

HYDROSCIENCE INC. Simplified mathematical modeling of water quality. Washington: EPA-Water Programs, U.S. Environmental Protection Agency, 1971. 
Methodology for minimum nitrogen compounds removal efficiencies estimation and wastewater treatment systems pre-selection: a watershed approach

JORDÃO, E. P.; PESSOA, C. A. Tratamento de esgotos domésticos. 7. ed. Rio de Janeiro: ABES, 2014.

LARENTIS, D. G. Modelagem matemática da qualidade da água em grandes bacias: sistema Taquari-Antas - RS. 2004. 177 f. Dissertação (Mestrado em Engenharia) - Universidade Federal do Rio Grande do Sul, Porto Alegre, 2004.

NYENJE, P. M.; FOPPEN, J. W.; UHLENBROOK, S.; KULABAKO, R.; MUWANGA, A. Eutrophication and nutrient release in urban areas of sub-Saharan Africa: a review. The Science of the Total Environment, v. 408, n. 3, p. 447-455, 2010. http://dx.doi. org/10.1016/j.scitotenv.2009.10.020. PMid:19889445.

REIS, J. A. T.; MENDONÇA, A. S. F. Análise técnica dos novos padrões brasileiros para amônia em efluentes e corpos d'água. Revista Engenharia Sanitária e Ambiental, v. 14, n. 3, p. 353-362, 2009. http://dx.doi.org/10.1590/S1413-41522009000300009.

SAADATPOUR, M.; AFSHAR, A. Waste load allocation modeling with fuzzy goals: simulation- optimization approach. Water Resources Management, v. 21, n. 7, p. 1207-1224, 2007. http://dx.doi. org/10.1007/s11269-006-9077-4.

SANTORO, M. C.; REIS, J. A. T.; MENDONÇA, A. S. F. Performance evaluation of optimization models in the determination of wastewater treatment efficiencies inside watersheds. Revista Brasileira de Recursos Hídricos, v. 21, n. 4, p. 694-706, 2016. http:/ / dx.doi.org/10.1590/2318-0331.011616031.

THOMANN, R. V.; MUELLER, J. A. Principles of surface water quality modeling and control. New York: Harper \& Row, 1987.

USEPA - UNITED STATES ENVIRONMENTAL PROTECTION AGENCY. The enhanced stream water quality models QUAL2E and QUAL2E-UNCAS: documentation and user model. Athens, 1987. 189 p.

VALORY, J. L.; REIS, J. A. T.; MENDONÇA, A. S. F. Combining genetic algorithms with a water quality model to determine efficiencies of sewage treatment systems in watersheds. Journal of Environmental Engineering, v. 142, n. 3,2016. http://dx.doi. org/10.1061/(ASCE)EE.1943-7870.0001048.
VALORY, J.; REIS, J.; MENDONÇA, A. Uso de otimização e modelagem de qualidade de água no planejamento de implantação de sistemas de tratamento de esgotos sanitários em bacias hidrográficas. Revista Brasileira de Recursos Hidricos, v. 18, n. 1, p. 277-286, 2013. http://dx.doi.org/10.21168/rbrh.v18n1.p277-286.

VON SPERLING, M. Princípios do tratamento biológico de águas residuárias: estudos e modelagem da qualidade da água de rios. Belo Horizonte: Departamento de Engenharia Sanitária e Ambiental, UFMG. 2014a.

VON SPERLING, M. Principios do tratamento biológico de águas residuárias: estudos e modelagem da qualidade da água de rios. 3. ed. Belo Horizonte: Ed. DESA/UFMG. 2014b.

ZENG, G.; JIANG, R.; HUANG, G.; XU, M.; LI, J. Optimization of wastewater treatment alternative selection by hierarchy grey relational analysis. Journal of Environmental Management, v. 82, n. 2, p. 250-259, 2007. http://dx.doi.org/10.1016/j.jenvman.2005.12.024. PMid:16635543.

\section{Authors contributions}

Glaucia de Laia Nascimento Sá: Acquisition of data, definition of optimization models, water quality simulation, determination of treatment efficiencies, selection of treatment systems, analysis and interpretation of results, drafting of manuscript and critical revision.

José Antonio Tosta dos Reis: Definition of optimization models, analysis and interpretation of results, drafting of manuscript and critical revision.

Antonio Sérgio Ferreira Mendonça: Analysis and interpretation of results, drafting of manuscript and critical revision.

Fernando das Graças Braga da Silva: Analysis and interpretation of results, drafting of manuscript and critical revision. 